\title{
Optimizing screening and management of cardiovascular health in prostate cancer
}

\author{
Miran Kenk ${ }^{1}$; Jean C. Grégoire ${ }^{2}$; Marc-Andre Coté ${ }^{3}$; Kim A. Connelly ${ }^{4}$ Margot K. \\ Davis $^{5}$; George Dresser ${ }^{6}$; Nina Ghosh ${ }^{7}$; Shaun Goodman ${ }^{8}$; Christopher Johnson ${ }^{9}$; Neil \\ Fleshner $^{1}$ \\ ${ }^{1}$ Department of Surgical Oncology, Princess Margaret Cancer Centre, University Health Network, Toronto, \\ ON, Canada; ${ }^{2}$ Montreal Heart Institute, Montreal, QC, Canada; ${ }^{3}$ Centre hospitalier universitaire de Quebec, \\ Québec City, QC, Canada; ${ }^{4}$ St. Michael's Hospital Li Ka Shing Knowledge Institute, Toronto, ON, Canada; \\ ${ }^{5}$ University of British Columbia Diamond Health Care Center, Vancouver, BC, Canada; ${ }^{6}$ Division of \\ Clinical Pharmacology, Department of Medicine, Western University, London, ON, Canada; ${ }^{7}$ Queensway \\ Carleton Hospital, University of Ottawa Heart Institute, Ottawa, ON, Canada; ${ }^{8}$ Division of Cardiology, St. \\ Michael's Hospital, Toronto, ON, Canada; ${ }^{9}$ Division of Cardiology, University of Ottawa, Ottawa, ON, \\ Canada
}

Funding: Ferring Canada provided support for the meeting between the co-authors, but did not have any input on the discussions or influence the resulting consensus.

Cite as: Can Urol Assoc J 2020 June 1; Epub ahead of print. http://dx.doi.org/10.5489/cuaj.6685

Published online June 1, 2020

$* * *$

\section{Abstract}

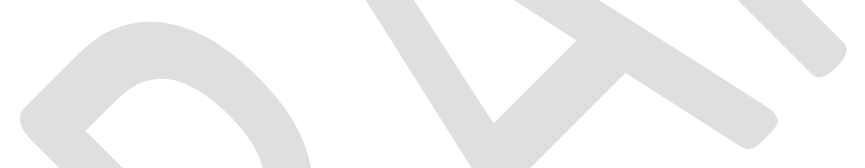

In clinical practice, cancer management does not consistently encompass screening and identification of cardiovascular (CV) risk. The use of androgen deprivation therapy (ADT) in prostate cancer has been associated with increased CV risk and development of metabolic syndrome, necessitating identification of patients at risk in this population (e.g., those with pre-existing CV disease). A multidisciplinary team of Canadian physicians was assembled to develop a series of recommendations intended to identify patients who may benefit from optimal management of their CV disease and/or modification of cardiac risk factors. A key goal was the development of a simple screening tool for identification of patients with pre-existing $\mathrm{CV}$ disease. This simple and inclusive set of recommendations are intended for use within urology clinics to facilitate holistic approaches and simplify the management of patients. 


\section{Prostate cancer and cardiovascular disease}

Prostate cancer is the most common form of cancer in men. Approximately 1 out of every 9 men will be diagnosed with the disease during their lifetime. ${ }^{1,2}$ The average age at diagnosis in North America is 66 years. Prevalence in North America is approximately 3 million, with approximately 200000 new cases diagnosed each year. Due to the relatively indolent nature of this form of cancer, only 1 in 41 men die of prostate cancer itself. ${ }^{1}$

In contrast, cardiovascular (CV) disease is a far more prevalent condition, with approximately 100 million men and women in North America either directly affected or considered to be at risk of the disease. ${ }^{3}$ It is the leading global cause of death, accounting for nearly 20 million deaths each year world-wide and approximately 1 million deaths per year in North America. ${ }^{3}$

Given the high prevalence of both conditions, the coexistence of prostate cancer and $\mathrm{CV}$ disease is inevitable. Furthermore, these two clinical conditions share a number of common risk factors such as advanced age, metabolic syndrome, visceral adiposity, and physical inactivity.

Important advances in the understanding of cancer biology have led to breakthrough treatments and a growing number of cancer survivors. However, both traditional and novel cancer treatments are associated with $\mathrm{CV}$ and metabolic complications. The adverse effects of these treatments increase the short- and long-term risk of CV events above and beyond the already elevated risk present in patients with cancer. The use of androgen deprivation therapy (ADT) in management of prostate cancer serves as an example: ADT has been used to treat this hormone-sensitive malignancy for decades and is accepted as front-line therapy for a large number of patients. However, ADT increases blood concentrations of total cholesterol and low-density lipoprotein cholesterol (LDL$\mathrm{C}$ ), and has been associated with a significantly increased risk of incident diabetes mellitus, coronary artery disease (CAD; including myocardial infarction [MI]), and sudden cardiac death. Furthermore, data from randomized oncology clinical trials have demonstrated that ADT increases mortality in patients with underlying CAD or heart failure (HF). Thus, optimal care of patients with cancer is best realized through a multidisciplinary approach whereby oncology and CV specialists partner (cardiooncology) in order to assess CV risk, minimize vascular and metabolic toxicity, and manage long-term adverse effects. ${ }^{4}$ This combined approach forms the basis for the emerging discipline of cardio-oncology.

\section{Metabolic syndrome, prostate cancer, and CV disease}

Metabolic syndrome has been proposed as a link between prostate cancer and CV complications. It is also, of itself, a risk factor for prostate cancer incidence, as well as progression to higher risk disease. ${ }^{5}$ Metabolic syndrome comprises multiple interconnected factors (biochemical, metabolic, physiological, and clinical) that increase 
the risk of type 2 diabetes and heart disease, resulting in early mortality. The current term metabolic syndrome was proposed in 1998 by the World Health Organization. ${ }^{6,7}$ In the ensuing decades, subspecialty societies have adopted their own modified definitions and criteria of this condition (Table 1).

A high prevalence of metabolic syndrome (51-55\%) was reported among ADTtreated patients. ${ }^{8-10}$ A meta-analysis demonstrated a $75 \%$ higher risk of metabolic syndrome and a $36 \%$ higher risk of diabetes in patients on ADT compared to controls ${ }^{11}$. Castration therapy among older men with prostate cancer can induce metabolic syndrome, ${ }^{12,13}$ and is associated with an elevated risk of CV disease and type 2 diabetes. ${ }^{14,15}$

With the prolonged survival of patients on modern ADT, consideration of metabolic syndrome and its associated $\mathrm{CV}$ risks is becoming increasingly important in the management of prostate cancer, particularly in the context of the potential impact on quality of life and health resource utilization. Awareness of the importance of metabolic syndrome has led to recent efforts to reduce the impact of ADT through exercise regimens,${ }^{16}$ which are limited by suboptimal adherence. ${ }^{17}$

In addition to the well-recognized association of metabolic syndrome with elevated risk of CV disease, stroke, and diabetes, there is increasing awareness of its other potential interactions. Recent studies suggest that cancers with high incidence in the developed countries (such as colorectal and breast cancers) may be linked to metabolic syndrome. ${ }^{18-22}$ Additionally, urological conditions are highly prevalent in aging men with metabolic syndrome. It is, therefore, crucial for urologists to be aware of metabolic syndrome and its constituent conditions, in terms of counseling and diagnosis.

The processes underlying metabolic syndrome are currently incompletely understood, with the associated physiological alterations not fully elucidated. The key characteristic is an energy imbalance, resulting from the interactions of genetic risk factors with environmental and lifestyle exposure (inactivity, tobacco smoking, excess caloric intake, pharmacological treatments, and psychological stress). Resulting adiposity is associated with abnormal fatty acid metabolism and stimulation of adipokines release. The resulting physiological abnormalities include endothelial dysfunction, insulin resistance, atherogenic dyslipidemia, hypertension, hypercoagulability, and a chronic low-grade inflammatory state.

At the vascular level, metabolic syndrome is characterized by impairments in endothelium-dependent vasodilatation and arterial compliance, as well as atherosclerosis ${ }^{23}$. These physiological abnormalities are mediated by factors including elevated levels of oxidative stress reactive species, hyperglycaemia, adipokines, glycation products, free fatty acids, and inflammatory cytokines. Metabolic syndrome induces a chronic proinflammatory state, with elevated circulating levels of cytokines and acute-phase reactants. Coagulation anomalies, including alterations in the procoagulant factors 
fibrinogen, factor VII, factor VIII, and the plasminogen activator inhibitor-1, suggest that pro-thrombotic and pro-inflammatory states may be metabolically linked.

\section{Targeting metabolic syndrome as a novel strategy in disease etiology}

With growing recognition of the associations between metabolic syndrome and prostate cancer, the potential interventions that would reverse the constituent features (e.g., obesity, insulin resistance) via lifestyle modifications or pharmacotherapy are a topic of intense study.

\section{Diet and exercise}

Physiological studies evaluating the effects of exercise on the androgen axis found increased blood concentrations of both testosterone and cortisol following physical exertion. While testosterone levels increase immediately following exercise, cortisol response tends to be slightly delayed. An exercise protocol needs to be of sufficient intensity and duration to induce these endocrine changes, with obese men requiring more vigorous exercise. ${ }^{24}$

\section{Statins}

HMG-CoA inhibitors are used for the management of hypercholesterolemia and for the primary and secondary prevention of $\mathrm{CV}$ events in men. Epidemiological association studies suggest a protective effect of statins against the progression of prostate cancer, ${ }^{25}$ warranting randomized trials. ${ }^{26}$

\section{Metformin}

Metformin is a biguanide drug used for treatment of type 2 diabetes. Metformin is believed to modify metabolism by inhibiting oxidative phosphorylation and thereby generating energetic stress in the liver ${ }^{27}$. Since early-stage prostate cancer predominantly relies on the oxidative phosphorylation pathway for energy generation, this effect may be potentially useful in management of early disease. Men receiving metformin for diabetes treatment were shown to have a lower risk of incidence and risk of death from prostate ${ }^{28}$ and other cancers, potentially including bladder carcinoma. ${ }^{29}$ Current understanding of the effects of metformin is limited by the retrospective nature of the published association studies. One small-scale intervention trial in which metformin was administered to nondiabetic men prior to radical prostatectomy has shown a reduction in the proliferation of cancer cells and alterations in the PTEN/PI3K-AKT signaling pathway involved in disease progression. ${ }^{30} \mathrm{~A}$ number of studies are currently in progress to address the lack of prospective data, including the MAST trial, ${ }^{31}$ a Canadian study aiming to randomize 408 patients with prostate cancer managed by active surveillance to receive metformin or placebo under an investigational protocol modeled after the REDEEM trial. ${ }^{32}$ 


\section{Treatment recommendations for patients with pre-existing $\mathrm{CV}$ disease}

Despite being widely viewed as separate diseases, there is a remarkable overlap in risk factors common to both CV disease and cancer. ${ }^{33}$ Hypertension, type 2 diabetes, tobacco use, and obesity are all highly prevalent in the aging population. A particularly high incidence is observed in individuals with prostate cancer, which remains the most common non-cutaneous malignancy in men. Recent data from an unselected population of 100 patients referred for ADT to a clinic at The University of British Columbia ${ }^{34}$ demonstrated that $39 \%$ of patients had a $\mathrm{CV}$ condition (including items such as arrhythmia, pericarditis, coronary vasospasm), $25 \%$ had pre-existing heart disease, and $50 \%$ had elevated CV risk, as determined by the Framingham risk score. Notably, only one third of patients at elevated CV risk were taking evidence-based therapies as recommended by the Canadian Cardiovascular Society $(\mathrm{CCS})^{35}$ and Diabetes Canada. ${ }^{36,37}$ Additionally, a number of other studies suggest that approximately one third of patients starting ADT have pre-existing CVD. ${ }^{37,38}$

A considerable amount of evidence supports the hypothesis that ADT is associated with a further increase in the risk of adverse CV events, including myocardial infarction and CV death. The majority of these data are derived from large observational studies involving patients receiving gonadotropin-releasing hormone $(\mathrm{GnRH})$ agonist therapy. ${ }^{37}$ However, it should be noted that randomized trial data do not support an association between ADT and CV events. ${ }^{39}$ A number of factors may explain this discrepancy, including a lack of rigorous adjudication of CV events in cancer trials, highly selected clinical trial populations with low background prevalence of CV disease and risk factors, competing risks in high-risk prostate cancer patients, and unmeasured bias in observational studies. While further prospective studies with pre-specified CV safety endpoints are needed to fully inform this issue, the safety signal identified in studies to date has already led the American Heart Association, American Cancer Society, and American Urologic Association to jointly issue a warning on CV consequences of prostate cancer treatments. ${ }^{40}$

It is well-established that ADT is associated with adverse metabolic effects, including metabolic syndrome and its components. ${ }^{41,42}$ Men treated with ADT have a $60 \%$ increased risk of incident diabetes ${ }^{43}$, while higher HbA1C values were observed in prostate cancer patients with pre-existing diabetes receiving ADT. Decreased lean body mass, increased visceral fat, and higher LDL concentration are also associated with ADT use. These metabolic risk factors, in turn, are associated with increased risk of atherosclerosis and vascular disease in the long term. ${ }^{41}$ However, it is difficult to explain the early risk of acute vascular events in patients receiving ADT on the basis of accelerated atherosclerosis alone. Importantly, the greatest risk has been observed in patients with pre-existing CV disease. ${ }^{42}$ While some of this risk may be due to the longterm adverse metabolic effects of ADT, the early separation of event curves (within one year of treatment initiation) suggests a more immediate effect, possibly mediated by 
accelerated plaque rupture in patients with pre-existing atherosclerotic disease. ${ }^{44}$ The transition from stable atherosclerotic plaque to vulnerable plaque is mediated, in large part, by the inflammatory system. ${ }^{45}$ LDL accumulating in the arterial intima undergo oxidation, leading to the recruitment of circulating monocytes in response to endothelial cell expression of adhesion molecules. Monocytes differentiate into tissue macrophages in response to cytokines. Tissue macrophages then engulf trapped LDL, becoming foam cells, and eventually dying to form the central necrotic core of atherosclerotic plaque. This central core is isolated from the circulation by a fibrous cap. In the presence of a thin fibrous cap, a large necrotic core, and ongoing inflammation, plaque may rupture, leading to acute vascular events. Animal studies have demonstrated that GnRH receptors co-localize with CD3+ T-lymphocytes at the sites of atherosclerotic plaques. ${ }^{46}$ In mouse models of atherosclerosis, treatment with GnRH agonists has been associated with increased numbers of tissue macrophages and increased plaque necrosis. ${ }^{46,47}$ It has therefore been hypothesized that GnRH agonists may upregulate immune system activity at the level of pre-existing atherosclerosis, leading to plaque destabilization and rupture.

$\mathrm{CV}$ risks have also been associated with other forms of hormonal therapy. Enzalutamide is associated with a nearly three-fold increase in the risk of hypertension, placing patients at risk for both long-term and short-term vascular events. ${ }^{48}$ Abiraterone is also associated with an increased risk of hypertension, as well as an increased risk of cardiac events, including heart failure. ${ }^{48-50}$ Androgen suppression, in general, is associated with a prolongation of the QT interval, and therefore theoretically increased risk of arrhythmia. ${ }^{51}$

\section{Patient selection}

In view of the $C V$ risks associated with ADT, it is essential that the use of these therapies be limited to patients who are likely to derive a net clinical benefit. ${ }^{52}$ Evidence clearly supports a net benefit among patients with metastatic or locally-advanced prostate cancer. ${ }^{53}$ Conversely, these benefits have not been reliably demonstrated in patients with low-risk prostate cancer. The importance of careful patient selection is illustrated by the results of the bicalutamide Early Prostate Cancer program. ${ }^{54}$ In three trials (with trial inclusion based on geographic region), progression-free survival (PFS) and overall survival (OS) were compared in patients with non-metastatic prostate cancer randomized to bicalutamide $150 \mathrm{mg}$ daily or placebo, in addition to standard care. In the Scandinavian trial, bicalutamide was associated with increased survival among patients with locally advanced disease but decreased survival among those with localized disease. ${ }^{55}$ In a review of the entire global program, there was a trend towards reduced survival with bicalutamide among patients managed with a watchful waiting approach, underscoring the lack of benefit in low-risk patients. 
Early data suggest that the risk of $\mathrm{CV}$ events may be lower in patients receiving $\mathrm{GnRH}$ antagonists compared to GnRH agonists. A pooled analysis of patients enrolled in six randomized trials of degarelix vs. GnRH agonists demonstrated a $56 \%$ relative reduction in the risk of $\mathrm{CV}$ events or death among those randomized to degarelix in the subgroup of patients with pre-existing CV disease. ${ }^{44}$ Additionally, a study comparing cardiac events in 80 patients randomized to 1 year of treatment with GnRH agonist or antagonist reported a higher number of patients experiencing a major cardiac event in agonist-treated group compared to antagonist-treated patients (20\% vs. $3 \%) .{ }^{56}$ It has been proposed that this risk difference may be due to the fact that $\mathrm{GnRH}$ antagonists suppress both luteinizing hormone ( $\mathrm{LH}$ ) and follicle-stimulating hormone (FSH), while GnRH agonists primarily suppress LH. Alternatively, relative risk may be mediated by $\mathrm{GnRH}$ receptors on the surface of T lymphocytes localized to sites of atherosclerotic plaque. Ongoing randomized studies, such as PRONOUNCE (ClinicalTrials.gov Identifier: NCT02663908), ${ }^{57}$ will provide additional insight into whether GnRH antagonists should be preferentially used instead of GnRH agonists in patients with established CV disease, in whom the risk of $\mathrm{CV}$ events is greatest. ${ }^{58}$

\section{Recommendations for patient management}

In order to aid the practitioner in diagnosing and treating patients with prostate cancer referred for ADT therapy, we recommend the following at the present time:

1) For every patient, collect routine medical history; perform a physical examination; determine the lipid profile; measure $\mathrm{HbA1c}$, uric acid, serum electrolytes, and creatinine; and complete blood count (CBC) and electrocardiogram (ECG).

2) Identify patients with "pre-existing" CV disease using the suggested "STAMP" questions (Table 2). If a person has any of these conditions, he should be considered for acetylsalicylic acid (ASA; Aspirin ${ }^{\circledR}$ ) and possibly additional antiplatelet or low-dose anti-coagulant therapy for higher risk patients, lipid lowering therapy (preferably a statin), and a renin-angiotensin system antagonist, as per CCS guidelines (Table 3), unless contraindicated or not tolerated.

3) Identify patients who may benefit from referral to a cardio-oncology clinic for additional evaluation or therapy (Table 4).

4) In patients without pre-existing $\mathrm{CV}$ disease (as described in \#2 and \#3 above), calculate a Framingham or equivalent risk score and treat accordingly.

Recommendation are the same as those for any patients concerned with keeping healthy: active lifestyle, physical activity, no smoking, good BP control, and body mass Index (BMI) less than 30 (ideally, less than 25).

While assessments listed in \#1 above can be performed by the health care practitioner treating the patient's prostate cancer, family doctors can be involved, as well. Similarly, family physicians can help in calculating risk scores and working with the patients to 
reduce CVD risks by encouraging a healthier lifestyle and addressing risk factor management.

In managing patients who meet the criteria in \#2 above, the physician should look for the following optimal conditions:

- Blood pressure below 140/90; for a diabetic patient, less than 130/80

- LDL less than $2.0 \mathrm{mmol} / \mathrm{L}$

- HbA1c less than $7 \%$

- Smoking cessation

- Exercise and active lifestyle

- Good compliance with medication

Patients who would benefit from a referral to a cardiologist or an internist (\#3 above) are those who exhibit:

- Angina or dyspnea on a low level of activity or any significant functional class deterioration

- Non-optimal treatment, as described in Table 3

- Myocardial infarction or coronary revascularization in the last year

- Cardiac patients without regular follow-up in cardiology or with the family physician

Recommended procedures listed above should be done in conjunction with the "ABCDE's" of management (Table 5) in order to reduce CV risk. A multifactorial approach addressing healthy lifestyle, glycemic control, blood pressure (BP) control, dyslipidemia management, and other $\mathrm{CV}$ protective measures was shown to effectively lower the risk of serious complications and mortality and may prolong life expectancy in individuals with prostate cancer ${ }^{59}$.

\section{Conclusions}

Epidemiological studies increasingly support the interconnections between cancer and $\mathrm{CV}$ health (including risk factors such as diabetes mellitus). Use of ADT in prostate cancer has been associated with development of metabolic syndrome and increased CV risk. Patients with pre-existing CV disease who initiate ADT are at higher risk of a subsequent cardiac event.

Physicians treating prostate cancer, such as urologists and radiation oncologists, are increasingly required to consider the patient's CV health in making treatment decisions. In this consensus statement, we propose an inclusive set of recommendations for identifying and managing patients with prostate cancer who have concomitant $\mathrm{CV}$ disease or risk factors. Included with these recommendations is a simple screening tool (STAMP) that physicians can use to readily identify the patients at highest risk and implement multidisciplinary management. 
Applying the presented recommendations within urology clinics should reduce the rate of potentially devastating $\mathrm{CV}$ events in patients with prostate cancer, decrease mortality, and improve the quality of life of patients.

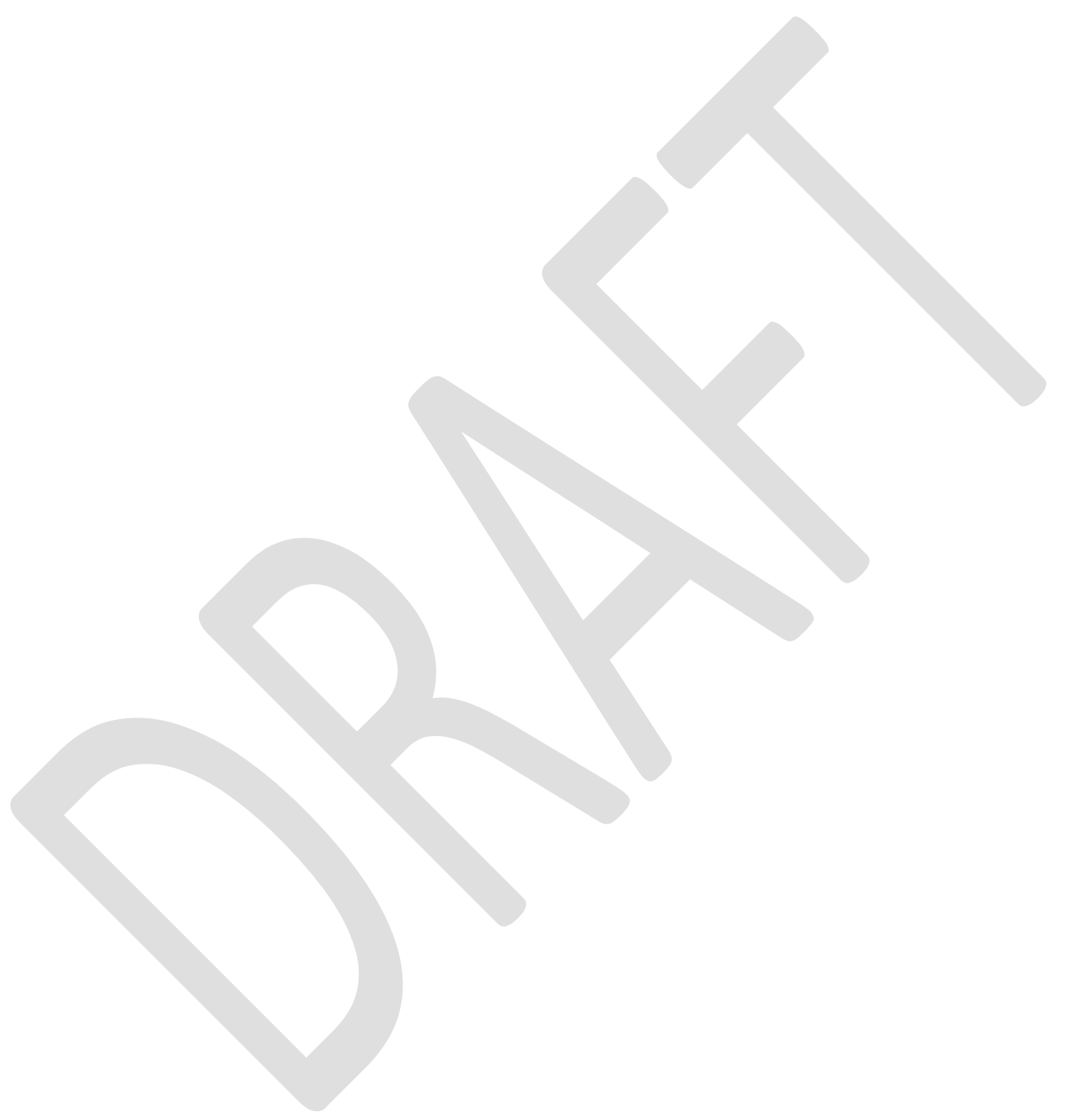




\section{References}

1. National Cancer Institute. SEER Cancer Stat Facts: Prostate Cancer. 2019; https://seer.cancer.gov/statfacts/html/prost.html. Accessed 23-Dec-2019, 2019.

2. Canadian Cancer Statistics Advisory Committee. Canadian Cancer Statistics 2019. Toronto, ON: Canadian Cancer Society; 2019.

3. Benjamin EJ, Muntner P, Alonso A, et al. Heart Disease and Stroke Statistics2019 Update: A Report From the American Heart Association. Circulation. 2019;139:e56-e528.

4. Campia U, Moslehi JJ, Amiri-Kordestani L, et al. Cardio-Oncology: Vascular and Metabolic Perspectives: A Scientific Statement From the American Heart Association. Circulation. 2019;139:e579-e602.

5. Bhindi B, Locke J, Alibhai SMH, et al. Dissecting the association between metabolic syndrome and prostate cancer risk: analysis of a large clinical cohort. Eur Urol. 2015;67:64-70.

6. Alberti KG, Zimmet PZ. Definition, diagnosis and classification of diabetes mellitus and its complications. Part 1: diagnosis and classification of diabetes mellitus provisional report of a WHO consultation. Diabet Med. 1998;15:539-53.

7. World Health Organization (WHO). Definition, diagnosis, and classification of diabetes mellitus and its complications. Report of a WHO Consultation Part 1: Diagnosis and classification of diabetes mellitus. Geneva 19991999.

8. Braga-Basaria M, Dobs AS, Muller DC, et al. Metabolic syndrome in men with prostate cancer undergoing long-term androgen-deprivation therapy. J Clin Oncol. 2006;24:3979-83.

9. Cleffi S, Neto AS, Reis LO, et al. [Androgen deprivation therapy and morbid obesity: do they share cardiovascular risk through metabolic syndrome?]. Actas Urol Esp. 2011;35:259-65.

10. Morote J, Ropero J, Planas J, et al. Metabolic syndrome in patients with prostate cancer undergoing androgen suppression. Actas Urol Esp. 2014;38:285-9.

11. Bosco C, Crawley D, Adolfsson J, Rudman S, Van Hemelrijck M. Quantifying the evidence for the risk of metabolic syndrome and its components following androgen deprivation therapy for prostate cancer: a meta-analysis. PLoS One. 2015;10:e0117344.

12. Faris JE, Smith MR. Metabolic sequelae associated with androgen deprivation therapy for prostate cancer. Curr Opin Endocrinol Diabetes Obes. 2010;17:240-6.

13. Morote J, Gomez-Caamano A, Alvarez-Ossorio JL, et al. The metabolic syndrome and its components in patients with prostate cancer on androgen deprivation therapy. J Urol. 2015;193:1963-9.

14. Alibhai SM, Duong-Hua M, Sutradhar R, et al. Impact of androgen deprivation therapy on cardiovascular disease and diabetes. J Clin Oncol. 2009;27:3452-8.

15. Keating NL, O'Malley AJ, Smith MR. Diabetes and cardiovascular disease during androgen deprivation therapy for prostate cancer. J Clin Oncol. 2006;24:4448-56.

16. Segal RJ, Reid RD, Courneya KS, et al. Resistance exercise in men receiving androgen deprivation therapy for prostate cancer. J Clin Oncol. 2003;21:1653-9. 
17. Carmack Taylor CL, Demoor C, Smith MA, et al. Active for Life After Cancer: a randomized trial examining a lifestyle physical activity program for prostate cancer patients. Psychooncology. 2006;15:847-62.

18. Esposito K, Chiodini P, Capuano A, et al. Colorectal cancer association with metabolic syndrome and its components: a systematic review with meta-analysis. Endocrine. 2013;44:634-47.

19. Bhandari R, Kelley GA, Hartley TA, Rockett IR. Metabolic syndrome is associated with increased breast cancer risk: a systematic review with metaanalysis. Int J Breast Cancer. 2014;2014:189384.

20. Esposito K, Chiodini P, Capuano A, et al. Metabolic syndrome and postmenopausal breast cancer: systematic review and meta-analysis. Menopause. 2013;20:1301-9.

21. Esposito K, Chiodini P, Colao A, Lenzi A, Giugliano D. Metabolic syndrome and risk of cancer: a systematic review and meta-analysis. Diabetes Care. 2012;35:2402-11.

22. Jinjuvadia R, Lohia P, Jinjuvadia C, Montoya S, Liangpunsakul S. The association between metabolic syndrome and colorectal neoplasm: systemic review and meta-analysis. J Clin Gastroenterol. 2013;47:33-44.

23. Kraemer-Aguiar LG, Laflor CM, Bouskela E. Skin microcirculatory dysfunction is already present in normoglycemic subjects with metabolic syndrome. Metabolism. 2008;57:1740-6.

24. Moradi F. Changes of Serum Adiponectin and Testosterone Concentrations Following Twelve Weeks Resistance Training in Obese Young Men. Asian J Sports Med. 2015;6:e23808.

25. Hamilton RJ, Freedland SJ. Review of recent evidence in support of a role for statins in the prevention of prostate cancer. Curr Opin Urol. 2008;18:333-9.

26. Clinicaltrials.gov. LIpitor and biGuanide to Androgen Delay Trial (LIGAND). USA: 2018 [cited 24-Apr-2018]. Available from: http://clinicaltrials.gov/ct2/show/NCT02497638. 2018.

27. Fleshner NE, Bhindi B. Metabolic syndrome and diabetes for the urologist. Can Urol Assoc J. 2014;8:S159-61.

28. Margel D, Urbach DR, Lipscombe LL, et al. Metformin use and all-cause and prostate cancer-specific mortality among men with diabetes. J Clin Oncol. 2013;31:3069-75.

29. Richard PO, Ahmad AE, Bashir S, et al. Impact of oral hypoglycemic agents on mortality among diabetic patients with non-muscle-invasive bladder cancer: A population-based analysis. Can Urol Assoc J. 2018.

30. Joshua AM, Zannella VE, Downes MR, et al. A pilot 'window of opportunity' neoadjuvant study of metformin in localised prostate cancer. Prostate Cancer Prostatic Dis. 2014;17:252-8.

31. Clinicaltrials.gov. The Metformin Active Surveillance Trial (MAST) Study. USA: 2018 [cited 24-Apr-2018]. Available from: http://clinicaltrials.gov/ct2/show/NCT01864096. . 
32. Fleshner NE, Lucia MS, Egerdie B, et al. Dutasteride in localised prostate cancer management: the REDEEM randomised, double-blind, placebo-controlled trial. Lancet. 2012;379:1103-11.

33. Johnson CB, Davis MK, Law A, Sulpher J. Shared Risk Factors for Cardiovascular Disease and Cancer: Implications for Preventive Health and Clinical Care in Oncology Patients. Can J Cardiol. 2016;32:900-7.

34. Davis MK, Rajala JL, Tyldesley S, Pickles T, Virani SA. The Prevalence of Cardiac Risk Factors in Men with Localized Prostate Cancer Undergoing Androgen Deprivation Therapy in British Columbia, Canada. J Oncol. 2015;2015:820403.

35. Anderson TJ, Gregoire J, Pearson GJ, et al. 2016 Canadian Cardiovascular Society Guidelines for the Management of Dyslipidemia for the Prevention of Cardiovascular Disease in the Adult. Can J Cardiol. 2016;32:1263-82.

36. Diabetes Canada Clinical Practice Guidelines Expert C, Stone JA, Houlden RL, Lin P, Udell JA, Verma S. Cardiovascular Protection in People With Diabetes. Can J Diabetes. 2018;42 Suppl 1:S162-S9.

37. Gandaglia G, Sun M, Popa I, et al. Cardiovascular mortality in patients with metastatic prostate cancer exposed to androgen deprivation therapy: a populationbased study. Clin Genitourin Cancer. 2015;13:e123-30.

38. Holmes JA, Anderson RF, Hoffman LG, et al. Cardiovascular Preventive Care and Coordination of Care in Prostate Cancer Survivors: A Multi-Institutional Prospective Study. Int J Radiat Oncol Biol Phys. 2019;103:112-5.

39. Nguyen PL, Je Y, Schutz FA, et al. Association of androgen deprivation therapy with cardiovascular death in patients with prostate cancer: a meta-analysis of randomized trials. JAMA. 2011;306:2359-66.

40. Levine GN, D'Amico AV, Berger P, et al. Androgen-deprivation therapy in prostate cancer and cardiovascular risk: a science advisory from the American Heart Association, American Cancer Society, and American Urological Association: endorsed by the American Society for Radiation Oncology. Circulation. 2010;121:833-40.

41. Kiwata JL, Dorff TB, Schroeder ET, Gross ME, Dieli-Conwright CM. A review of clinical effects associated with metabolic syndrome and exercise in prostate cancer patients. Prostate Cancer Prostatic Dis. 2016;19:323-32.

42. O'Farrell S, Garmo H, Holmberg L, Adolfsson J, Stattin P, Van Hemelrijck M. Risk and timing of cardiovascular disease after androgen-deprivation therapy in men with prostate cancer. J Clin Oncol. 2015;33:1243-51.

43. Dockery F, Bulpitt CJ, Agarwal S, Donaldson M, Rajkumar C. Testosterone suppression in men with prostate cancer leads to an increase in arterial stiffness and hyperinsulinaemia. Clin Sci (Lond). 2003;104:195-201.

44. Albertsen PC, Klotz L, Tombal B, Grady J, Olesen TK, Nilsson J. Cardiovascular morbidity associated with gonadotropin releasing hormone agonists and an antagonist. Eur Urol. 2014;65:565-73.

45. Gistera A, Hansson GK. The immunology of atherosclerosis. Nat Rev Nephrol. 2017; 13:368-80. 
46. Knutsson A, Hsiung S, Celik S, et al. Treatment with a GnRH receptor agonist, but not the GnRH receptor antagonist degarelix, induces atherosclerotic plaque instability in ApoE(-/-) mice. Sci Rep. 2016;6:26220.

47. Hopmans SN, Duivenvoorden WC, Werstuck GH, Klotz L, Pinthus JH. GnRH antagonist associates with less adiposity and reduced characteristics of metabolic syndrome and atherosclerosis compared with orchiectomy and $\mathrm{GnRH}$ agonist in a preclinical mouse model. Urol Oncol. 2014;32:1126-34.

48. Iacovelli R, Ciccarese C, Bria E, et al. The Cardiovascular Toxicity of Abiraterone and Enzalutamide in Prostate Cancer. Clin Genitourin Cancer. 2018;16:e645-e53.

49. Lu-Yao G, Nikita N, Keith SW, et al. Mortality and Hospitalization Risk Following Oral Androgen Signaling Inhibitors Among Men with Advanced Prostate Cancer by Pre-existing Cardiovascular Comorbidities. Eur Urol. 2020;77:158-66.

50. Lu-Yao GL, Albertsen PC, Moore DF, et al. Survival following primary androgen deprivation therapy among men with localized prostate cancer. JAMA. 2008;300:173-81.

51. Gagliano-Juca T, Travison TG, Kantoff PW, et al. Androgen Deprivation Therapy Is Associated With Prolongation of QTc Interval in Men With Prostate Cancer. $J$ Endocr Soc. 2018;2:485-96.

52. Lester-Coll NH, Goldhaber SZ, Sher DJ, D'Amico AV. Death from high-risk prostate cancer versus cardiovascular mortality with hormonal therapy: a decision analysis. Cancer. 2013;119:1808-15.

53. Pagliarulo V, Bracarda S, Eisenberger MA, et al. Contemporary role of androgen deprivation therapy for prostate cancer. Eur Urol. 2012;61:11-25.

54. Wirth MP, See WA, McLeod DG, et al. Bicalutamide $150 \mathrm{mg}$ in addition to standard care in patients with localized or locally advanced prostate cancer: results from the second analysis of the early prostate cancer program at median followup of 5.4 years. J Urol. 2004;172:1865-70.

55. Iversen $\mathrm{P}$, Johansson JE, Lodding $\mathrm{P}$, et al. Bicalutamide $(150 \mathrm{mg})$ versus placebo as immediate therapy alone or as adjuvant to therapy with curative intent for early nonmetastatic prostate cancer: 5.3-year median followup from the Scandinavian Prostate Cancer Group Study Number 6. J Urol. 2004;172:1871-6.

56. Margel D, Peer A, Ber Y, et al. Cardiovascular Morbidity in a Randomized Trial Comparing GnRH Agonist and GnRH Antagonist among Patients with Advanced Prostate Cancer and Preexisting Cardiovascular Disease. J Urol. 2019;202:1199208.

57. Slovin SF, Melloni C, Mansor-Lefebvre S, Neijber A, Roe M. A multicenter, randomized, controlled trial comparing the occurrence of major adverse cardiovascular events (MACEs) in patients (pts) with prostate cancer (pc) and cardiovascular disease (CVD) receiving degarelix ( $\mathrm{GnRH}$ receptor antagonist) or leuprolide (GnRH receptor agonist). Journal of Clinical Oncology. 2018;36:TPS395-TPS. 
58. Rosario DJ, Davey P, Green J, et al. The role of gonadotrophin-releasing hormone antagonists in the treatment of patients with advanced hormone-dependent prostate cancer in the UK. World J Urol. 2016;34:1601-9.

59. Virani SA, Dent S, Brezden-Masley C, et al. Canadian Cardiovascular Society Guidelines for Evaluation and Management of Cardiovascular Complications of Cancer Therapy. Can J Cardiol. 2016;32:831-41. 


\section{Figures and Tables}

\begin{tabular}{|c|c|c|c|c|c|}
\hline $\begin{array}{l}\text { Clinical } \\
\text { parameter }\end{array}$ & WHO (1998) & EGIR (1999) & ATP III (2001) & AACE (2003) & IDF (2005) \\
\hline $\begin{array}{l}\text { Obesity/body fat } \\
\text { distribution }\end{array}$ & $\begin{array}{c}\text { Waist } / \text { hip ratio }>0.90 \\
\text { in men, }>0.85 \text { in } \\
\text { women; or BMI }>30 \\
\mathrm{~kg} / \mathrm{m}^{2}\end{array}$ & $\begin{array}{c}\text { Waist } \\
\text { circumference } \geq 94 \\
\mathrm{~cm} \text { in men, } \geq 80 \mathrm{~cm} \\
\text { in women }\end{array}$ & $\begin{array}{c}\text { Waist } \\
\text { circumference }>102 \\
\mathrm{~cm} \text { in men, }>88 \mathrm{~cm} \\
\text { in women. }\end{array}$ & $\mathrm{BMI} \geq 25 \mathrm{~kg} / \mathrm{m}^{2}$ & $\begin{array}{l}\text { Waist circumference } \\
\geq 94 \mathrm{~cm} \text { in men, } \geq 80 \\
\mathrm{~cm} \text { in women }\end{array}$ \\
\hline $\begin{array}{l}\text { Insulin } \\
\text { resistance/ } \\
\text { hyperglycemia }\end{array}$ & $\begin{array}{l}\text { IGT, IFG, T2DM, or } \\
\text { other evidence of } \\
\text { insulin resistance }\end{array}$ & $\begin{array}{l}\text { Hyperinsulinemia } \\
\text { (plasma insulin } \\
>75^{\text {th }} \text { percentile) }\end{array}$ & $\begin{array}{c}\text { Fasting glucose } \\
\geq 110 \mathrm{mg} / \mathrm{dL}(6.1 \\
\mathrm{mmol} / \mathrm{L})\end{array}$ & $\begin{array}{l}\text { Fasting glucose } \\
\geq 110 \mathrm{mg} / \mathrm{dL}(6.1 \\
\mathrm{mmol} / \mathrm{L})\end{array}$ & $\begin{array}{c}\text { Fasting glucose } \geq 100 \\
\mathrm{mg} / \mathrm{dL}(5.5 \mathrm{mmol} / \mathrm{L}) \\
\text { T2DM }\end{array}$ \\
\hline Triglyceridemia & $\begin{array}{c}\geq 150 \mathrm{mg} / \mathrm{dL}(1.7 \\
\mathrm{mmol} / \mathrm{L})\end{array}$ & $\begin{array}{c}177 \mathrm{mg} / \mathrm{dL}(2.0 \\
\mathrm{mmol} / \mathrm{L})\end{array}$ & $\begin{array}{c}\geq 150 \mathrm{mg} / \mathrm{dL}(1.7 \\
\mathrm{mmol} / \mathrm{L})\end{array}$ & $\begin{array}{l}>150 \mathrm{mg} / \mathrm{dL} \\
(1.7 \mathrm{mmol} / \mathrm{L})\end{array}$ & $\begin{array}{c}>150 \mathrm{mg} / \mathrm{dL}(1.7 \\
\mathrm{mmol} / \mathrm{L}) \text { or on } \\
\text { treatment }\end{array}$ \\
\hline Cholesterol & $\begin{array}{l}\mathrm{HDL}-\mathrm{C}<35 \mathrm{mg} / \mathrm{dL} \\
(0.9 \mathrm{mmol} / \mathrm{L}) \mathrm{in} \text { men } \\
\text { or }<39 \mathrm{mg} / \mathrm{dL}(1.0 \\
\mathrm{mmol} / \mathrm{L}) \text { in women }\end{array}$ & $\begin{array}{c}\text { HDL-C } \\
<39 \mathrm{mg} / \mathrm{dL}(1.0 \\
\mathrm{mmol} / \mathrm{L})\end{array}$ & $\begin{array}{c}\text { HDL-C }<40 \mathrm{mg} / \mathrm{dL} \\
\text { in men }(1.0 \\
\mathrm{mmol} / \mathrm{L}) ;<50 \\
\mathrm{mg} / \mathrm{dL}(1.3 \\
\mathrm{mmol} / \mathrm{L})_{-} \text {in } \\
\text { women }\end{array}$ & $\begin{array}{c}\mathrm{HDL}-\mathrm{C}<40 \\
\mathrm{mg} / \mathrm{dL}(1.0 \\
\mathrm{mmol} / \mathrm{L}) \text { in men; } \\
<50 \mathrm{mg} / \mathrm{dL}(1.3 \\
\mathrm{mmol} / \mathrm{L}) \text { in } \\
\text { women }\end{array}$ & $\begin{array}{l}\text { HDL-C }<40 \mathrm{mg} / \mathrm{dL} \\
(1.0 \mathrm{mmol} / \mathrm{L}) \text { in men; } \\
<50 \mathrm{mg} / \mathrm{dL}(1.3 \\
\mathrm{mmol} / \mathrm{L}) \text { in women; } \\
\text { or on treatment }\end{array}$ \\
\hline Blood pressure & $\geq 140 / 90 \mathrm{mmHg}$ & $\begin{array}{l}\geq 140 / 90 \mathrm{mmHg} \text { or } \\
\text { on treatment }\end{array}$ & $>130 / 85 \mathrm{mmHg}$ & $\geq 130 / 85 \mathrm{mmHg}$ & $\begin{array}{c}>130 / 85 \mathrm{mmHg} \text { or on } \\
\text { treatment }\end{array}$ \\
\hline
\end{tabular}




\begin{tabular}{|l|l|l|l|l|}
\hline Other & Microalbuminuria $^{\mathrm{a}}$ & & $\begin{array}{c}\text { Other features of } \\
\text { insulin } \\
\text { resistance }^{\mathrm{b}}\end{array}$ & \\
\hline
\end{tabular}

${ }^{\mathrm{a}}$ Microalbuminuria defined as urinary albumin excretion $\geq 70 \mu \mathrm{g} / \mathrm{min}$ or albumin/creatine ratio $\geq 30 \mathrm{mg} / \mathrm{g}$. ${ }^{\mathrm{b}}$ Family history of T2DM, hypertension, or CVD; polycystic ovary syndrome; sedentary lifestyle; advancing age; ethnic groups having high risk for T2DM or CVD. AACE: American Association of Clinical Endocrinologists; ATP III: National Cholesterol Education Program Adult Treatment Panel III Report; BMI: body mass index; EGIR: European Group for the Study of Insulin Resistance; HDL-C: high-density lipoprotein cholesterol; IDF: International Diabetes Federation; IGT: impaired glucose tolerance; IFG: impaired fasting glucose; T2DM: type II diabetes mellitus; WHO: World Health Organization.

\begin{tabular}{|l|l|}
\hline \multicolumn{2}{|l|}{ Table 2. STAMP - Identification of patients with cardiovascular disease } \\
\hline S & Stroke \\
\hline T & Transient ischemic attack \\
\hline A & Abdominal aortic aneurysm or other aortic disease \\
\hline $\mathbf{M}$ & Myocardial infarction, angina, or previous coronary revascularization \\
\hline $\mathbf{P}$ & Peripheral arterial disease \\
\hline
\end{tabular}




\begin{tabular}{|c|c|c|}
\hline Category & Population & Recommendation \\
\hline \multirow[t]{2}{*}{$\begin{array}{l}\text { Antithrombotic } \\
\text { therapy }\end{array}$} & $\begin{array}{l}\text { MI in past } 12 \\
\text { months } \\
\text { PCI with DES in } \\
\text { past } 3-12 \text { months (or } \\
\text { BMS in past } 1 \\
\text { month) }\end{array}$ & $\begin{array}{l}\text { ASA } 81 \mathrm{mg} \text { daily AND } \\
\text { P2Y12 inhibitor (ticagrelor or clopidogrel) }\end{array}$ \\
\hline & All others & $\begin{array}{l}\text { ASA } 81 \mathrm{mg} \text { daily; consider either rivaroxaban } 2.5 \mathrm{mg} \text { BID or } \\
\text { ticagrelor } 60 \mathrm{mg} \text { BID (or clopidogrel } 75 \mathrm{mg} \text { daily) for higher } \\
\text { risk patients }\end{array}$ \\
\hline $\begin{array}{l}\text { Lipid-lowering } \\
\text { therapy }\end{array}$ & All & $\begin{array}{l}\text { Statin therapy to target a decrease in LDL of } \geq 50 \% \text { or LDL } \\
<2.0 \\
\text { Additional lipid-lowering therapy if unable to reach target } \\
\text { with maximal tolerated statin dose (as per CCS lipid } \\
\text { guidelines) }\end{array}$ \\
\hline ACE or ARB & All & $\begin{array}{l}\text { ACE inhibitor } \\
\text { ARB if ACE-intolerant }\end{array}$ \\
\hline \multirow[t]{2}{*}{ B blocker } & Angina & Target HR 55-60 bpm \\
\hline & $\mathrm{LVEF} \leq 40 \%$ & $\begin{array}{l}\text { Metoprolol succinate, bisoprolol, or carvedilol at maximally } \\
\text { tolerated HF doses }\end{array}$ \\
\hline $\begin{array}{l}\text { Anti-hyperglycemic } \\
\text { therapy }\end{array}$ & Diabetes & $\begin{array}{l}\text { HbA1C }<7 \% \\
\text { Consider SGLT2 inhibitor or GLP1RA as per DC guidelines }\end{array}$ \\
\hline Smoking cessation & All & $\begin{array}{l}\text { Benefits of nicotine replacement or pharmacologic therapy } \\
\text { outweigh risks in stable patients }\end{array}$ \\
\hline $\begin{array}{l}\text { Physical activity and } \\
\text { dietary modification }\end{array}$ & All & Consider cardiac rehab referral \\
\hline
\end{tabular}

ACE: angiotensin-converting enzyme; ARB: angiotensin II receptor blocker; ASA: acetylsalicylic acid; BID: twice daily; BMS: bare metal stents; DC: DES: drug-eluting stents; LDL: low-density lipoprotein; CCS: Canadian Cardiovascular Society; HF: heart failure; LHR: heart rate; LVEF: left ventricular ejection fraction; MI: myocardial infarction; PCI: percutaneous coronary intervention. 


\begin{tabular}{|l|l|}
\hline \multicolumn{2}{|l|}{ Table 4. Comorbidities that may benefit from cardio-oncology clinic referral } \\
\hline Condition & Additional treatment that may be indicated \\
\hline $\begin{array}{l}\text { Heart failure or } \\
\text { impaired LV or RV } \\
\text { function }\end{array}$ & $\begin{array}{l}\text { Diuresis } \\
\text { LV enhancement therapy ( } \beta \text { blocker, ACE/ARB/ARNI, MRA, } \\
\text { ivabradine) } \\
\text { Device therapy as per CCS HF guidelines }\end{array}$ \\
\hline $\begin{array}{l}\text { Atrial } \\
\text { fibrillation/flutter }\end{array}$ & $\begin{array}{l}\text { Stroke prevention therapy as per CCS AF guidelines } \\
\text { Rate or rhythm control (including ablation) }\end{array}$ \\
\hline $\begin{array}{l}\text { Uncontrolled } \\
\text { hypertension }\end{array}$ & $\begin{array}{l}\text { Antihypertensive therapy as per Canadian Hypertension } \\
\text { Education Program (CHEP) guidelines }\end{array}$ \\
\hline $\begin{array}{l}\text { Uncontrolled } \\
\text { diabetes }\end{array}$ & $\begin{array}{l}\text { Anti-hyperglycemic therapy as per Diabetes Canada (DC) } \\
\text { guidelines }\end{array}$ \\
\hline
\end{tabular}

ACE: angiotensin-converting enzyme; AF: atrial fibrillation; ARB: angiotensin II receptor blocker; ARNI: angiotensin receptor II blocker - neprilysin inhibitor; CCS: Canadian Cardiovascular Society; HF: heart failure; LV: left ventricular; RV: right ventricular; MRA: magnetic resonance angiogram.

\begin{tabular}{|l|l|}
\hline \multicolumn{2}{|l|}{ Table 5. ABCDE of management of CVD risk } \\
\hline A & $\begin{array}{l}\text { Assessment of risk } \\
\text { Antiplatelet therapy }\end{array}$ \\
\hline B & Blood pressure \\
\hline C & $\begin{array}{l}\text { Cholesterol } \\
\text { Cigarette/tobacco cessation }\end{array}$ \\
\hline D & $\begin{array}{l}\text { Diet and weight management } \\
\text { Diabetes prevention and treatment }\end{array}$ \\
\hline E & Exercise \\
\hline
\end{tabular}

From Hsu et al, 2013. CVD: cardiovascular disease. 